\title{
Assessment of an in situ Real Time UV/VIS Based Spectrometry System for Chemical 0xygen Demand Measurement in a Wastewater Anaerobic Treatment Reactor
}

Hernández. O.A.D. ${ }^{1}$ Lisboa, A.M. ${ }^{2}$ Cantã o, M.P. ${ }^{3}$, Possetti, G.R.C. ${ }^{2}$, Aisse, M.M. ${ }^{3}$

IInd ustrial Engineer (Universidad Nacional Experimental del Tachira - UNET, Venezuela), Master in Environmental Management and Audits (Universidad Europea Miguel de Cervantes - UEMC, Spain), Tea cher in the Universidad Nacional Experimental del Tachira - UNET, Doctorate in Water Resources and Environmental Engineering (Federal University of Pa ra ná - UFPR, Brazil).

${ }^{2}$ Research and Development Advisory, Companhia de Saneamento do Paraná (SANEPAR, Brazil).

${ }^{3} \mathrm{G}$ raduate Program in Water Resources and Environmental Engineering (PPGERHA, Federal University of Pa raná - UFPR, Bra zil).

*Correspondence author: oranduherl@gmail.com

\section{Abstract}

Analysis of physic al and chemic al parameters is more and more important for operation chec king and performance control in wastewater treatment plants (WWTP). Recently developed UV/VIS spectrometry based sensors are being used for measurement of parameters like chemical oxygen demand (COD). The a im of this work is to report results ofreal time in situ COD measurementusing a spectrophotometric system in a wa stewa ter trea tment plant with upflowa na ero bic sludg eblanket (UASB). The studies 
focused a medium size WWTP (wastewater average flow a round $319 \mathrm{~L} / \mathrm{s}$ ) located in Paraná State (Brazil), and used several statistical tools, like as rela tive error, boxplot charts, statistical dispersion, Student's t-test (significance level $a=0.05$ ) and bilateral test, to compare measurement system results with la boratorial a nalyses. The results indic ate that sensor monitoring can be effective for the UASB affluent, as the probe mea surement results a nd la bora to rial a na lyses of COD showed no sta tistic al signific a nt difference for three different calibration scenarios. Linear local calibration showed the best performance in the assessed WWTP, with mean error being $4.32 \%$, standard deviation $\sigma=2.76 \%$ and determination coefficient $\mathrm{R}^{2}=0.7667$. For the UASB reactor effluent the behavior has not shown the expected adherence: only the offset calibration, among four assessed methods, showed no signific ant difference, with mean error being $27.53 \%$, standard deviation $\sigma=24.11 \%$ and determination coefficient $\mathrm{R}^{2}=0.1246$. COD removal efficiency in the WTP was between $56 \%$ and $60 \%$.

Keywords: UV/VIS Spec tro photometry, COD, UASB, Probe, Sa nitation System.

\section{Introduction}

In the wastewater treatment plants of Brazil, and of Paraná Sta te in particular, the upflow anaerobic sludge blanket (UASB) treatment method is prevailing, due to its low energy consumption, reduced a rea requirement and higher operational simplic ity. Besides, UASB reactors have low sludge production and reduced implantation cost (CHERNIC HARO et al., 1999).

Sampling and analysis a re more and more important for treatment plants operation assessment, since the highquality data of present systems allow plant monitoring. Traditional approach is based on punctual short runs for sampling and later laboratory a nalyses, which use to be leng thy, demand expensive and/ortoxic reagents and produce residues needing la ter trea tment (VANRO LLEG HEM, LEE, 2003; BRITO et al.,2014).
Usually assessed parameters, like as tempera ture, $\mathrm{pH}$ and conductivity a mong others, can be continuously monitored. In the last few years some papers reported the monitoring of total organic carbon (TOC), tota I suspended solids (TSS) and chemical oxygen demand (COD) using spectrometric techniques (BRITO et al., 2014).

The chemical oxygen demand is a global parameter very used as ind ic ator of oxygen content in design and control of UASB ana erobic trea tment systems (CHERNICHARO et al., 2015). Aisse et al. (2002) obtained COD = $151 \pm 64 \mathrm{mg} / \mathrm{L}$ as a typical value for the effluent of domestic wastewater treated in UASB reactor. Considering a value of $453 \pm 147$ $\mathrm{mg} / \mathrm{L}$ for COD in the affluent the a uthors determined a removal efficiency of $69 \%$. The volumetric organic load (VOL) can be assumed to be $1.80 \mathrm{~kg}(\mathrm{COD}) \cdot \mathrm{m}^{-3} \cdot \mathrm{day}^{-1}$, for a hydraulic retention time of 8 hours. 
The full UV spectrum has been used for the TOC, COD and biochemical oxygen demand $\left(\mathrm{BOD}_{5}\right)$ estimation in wa stewater (THOMAS et al., 1997). The spectrometry in the ultra violet and visible ranges (UV/ VIS) a llows to obta in releva nt information (VAN DEL BROEKE et al., 2006; BRITO et al., 2014). It is a fast and easy to implement technique, used for wastewater quality assessment (THOMAS et al., 2005). The used wavelength varies from 200 to $800 \mathrm{~nm}$, and it is possible to relate the radiation absorbance features (absorption wavelength ranges) with the compounds that account for COD values.

In the measurement process it is very important to consider the sample peculia rities (matrix effect) and assessment of the error, which can be reduced with previous calibration and with control of local sampling variables, such as flow fluctuation, coarse solids and equipment cleansing. A good monitoring depends on true results. Van der Broke et al. (2006) affirm that online spectra a cquisition has been implemented in most WWTP. One can a dmit that mea surement instruments must deal with additional c hallenges, due to water quality matrix va riability and to facility related operation and safety issues (BRITO et al., 2014). There are few works in Brazil that support the installation of in situ COD real time probes in UASB reactors based WWTP.

In this respect, the objective of this work is to report the results of using a spectrophotometric measurement system for real time in situ COD determination in a wastewater trea tment plant with up flow anaerobic sludge blanket reactor.

\section{Metodology}

\section{Location of Study}

This study took place in a medium size WWTP with a verage flow of $319 \mathrm{~L} / \mathrm{s}$, located in Curitiba, PR. The wastewater pretreatment occurs in a system composed of $20 \mathrm{~mm}$ manual screen, $3 \mathrm{~mm}$ mechanic al sc reen, grit removal system, Pa rshall flume and the biological treatment is done in six UASB reactors, each one with rated c apacity of 70 L/s.Post treatment of a naerobic effluent post-trea tment could take place in aerated facultative ponds.

\section{Wastewater COD Concentration Meter (Probe)}

The COD measurement system, Carbolyser model supplied by S::can (shown in Figure 1) is composed of a probe and a control unit. The system can determine concentrations between 100 and 3,250 mg(COD)/L using UV/VIS spectrophotometry. The probe measures the difference between optical intensity emitted by a lamp inside the measuring window and the optical intensity that reaches the detector, after crossing the waste water flow. The probe is $0.6 \mathrm{~m}$ in length and $44 \mathrm{~mm}$ in diameter, operates in a wavelength range between 200 and $750 \mathrm{~nm}$ and uses a xenon la mp. 


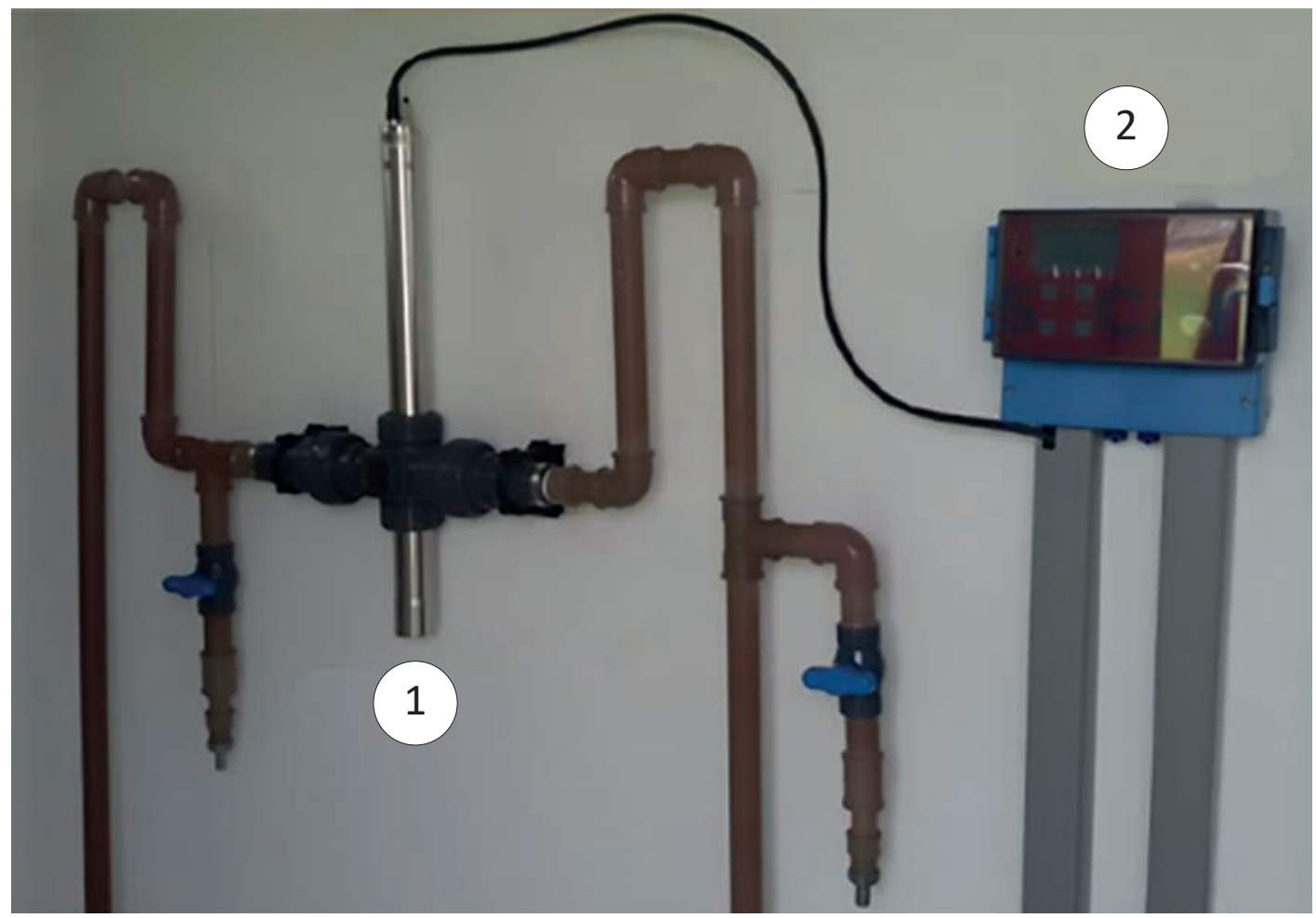

Figure 1-COD probe installation layout. Notes: (1) Carbolyser probe (spectrophotometer); (2) Equipment control display.

The insta lla tion of the instrument in the WTP allowed the assessment of a ffluent to and effluent from the UASB reactor, using an automated pumping system for altema te sampling of affluent and effluent flows.

The COD measurement system has a compressed a ir self-cleaning system with maximum pressure of 5 bar; manual cleaning is also allowed. The cleaning procedure, developed for the removal of solid deposits from the measurement hollow, includes the use of lukewarm water, pure ethanol and brushes provided by the manufacturer. The frequency of the manualcleaning wasincreased from biweekly to two times a week after day 14 reading.
Calibration Methods and Comparison with Laboratory Analyses

Besides the real-time mea surements, collec ted wastewater samples were analyzed in laboratory, through procedures preconized in the APHA Standard Methods (APHA, 2012).At laboratory the samples were transferred to a digestion flask at 150 ㄷ for 2 hours. COD was determined by colorimetric method based on absorbance measurement at $620 \mathrm{~nm}$ in a workbench spectrophotometer DR6000 (Hach Ind ustries) and previous calibration curve. Total 25 affluent and 29 effluent sa mples were collected in different days, between 9:00 and 11:00 am and during summer and a utumn of 2016. 
The calibration of the COD measurement system installed in the WTP was done so that the samples covered the historic va riation of wastewater concentration values. Three scenarios were outlined for affluent COD readings: 1 ) global calibration (from factory), 2) local offset calibration (for both field and laboratory measurements, used to fit the global calibration to present situation, shifting the position but not the inclination of global calibration curve), and 3) local linear calibration (from two field samples and two laboratory results, global calibration inclination and alignment change). For the effluent COD recording 4 scenarios were proposed: 1) global calibration (from factory), 2) local offset calibration, 3) local linearcalibration, and 4) new calibration curve supplied by the manufacturer.

Results were a nalyzed with statistic al tools such as percentage mean error, boxplot charts, sc atter plots, Student's t-test, for two samples with presumed equivalent variances and significance level $a=0.05$, and bilateral test, to compare results obta ined from measurement system at WTP with la boratory a nalyses.

\section{Results and Discussion}

Figure 2 shows the rela tive error between values registered by mea surement system installed in WTP and values obtained in the laboratory analyses, for wastewa ter affluent samples. Mean relative error va lues is $64.7 \%$ $\pm 64.0 \%$ for global ca lib ration (rea ding days \#1 to \#11), $38.3 \pm 40.5 \%$ for offset calibration (\#11 to \#20) and $4.3 \pm 2.8 \%$ for local linearcalibration (\#21 to \#25). The improved probe performance from day \#16 can be attributed to the increased cleaning frequency (from biweekly to two times a week) from day \#14.

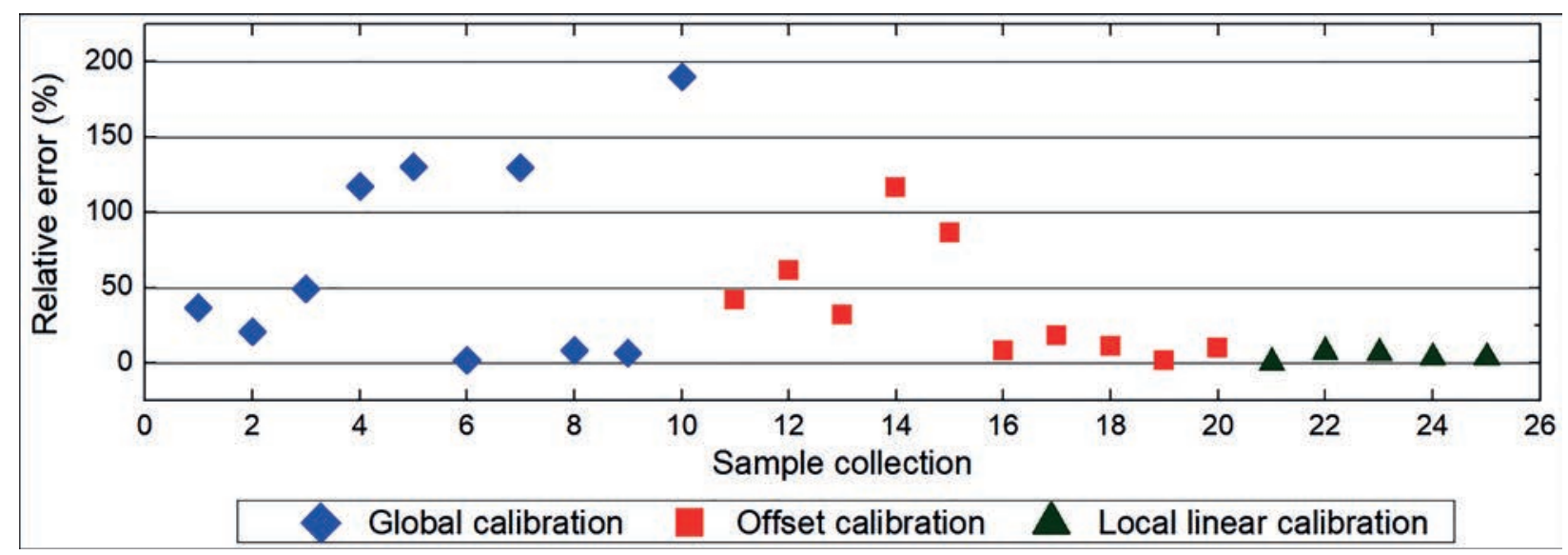

Figure 2 - Relative error scatter plot for the affluent in the calibration modes: global, offset and local linear. 
Figure 3 shows the COD boxplot charts for the wastewater affluent, measured by the probe and in the laboratory. For global calibration (Figure $3 a$ ) the a verage probe measured COD is $708 \pm 252 \mathrm{mg} / \mathrm{L}$ and $486 \pm 250 \mathrm{mg} / \mathrm{L}$ at the laboratory; in the case of offset calibration (Figure $3 b$ ) probe average COD is $705 \pm 152 \mathrm{mg} / \mathrm{L}$ and laboratory a verage, $562 \pm 190 \mathrm{mg} / \mathrm{L}$; for the local linear calibration (Figure $3 c)$, probe average COD is much closer to laboratory a verage: $650 \pm 52 \mathrm{mg} / \mathrm{L}$ (probe) and $651 \pm 73 \mathrm{mg} / \mathrm{L}$ (laboratory). The linear calibration has shown the best results among the three scenarios.

The applic a tion of Student's t-test in all the three calibration scenarios has not shown signific ant differences. Nevertheless, it is clearfrom Figures 2 and $3 c$ that linear calibration is the best one in comparison with global (manufacturer) and offset calibrations, based on its lowest rela tive error, equal to $4.3 \%$, and on the lowest difference between probe and laboratory averages.

Figure 4 shows the scatter plots of affluent COD results obtained with laboratory a na lyses versus mea surements obta ined with the probe at WTP, assessed with the three different calibration scenarios. The following determination coefficient $\left(R^{2}\right)$ values were found: 0,6178 for global calibration (Figure 4a), 0,4612 for local offset calibration (Figure 4b) and 0,7667 for local linear calibration. Aga in, the loc al linear calibration scenario is the more adequate to the studied situation.

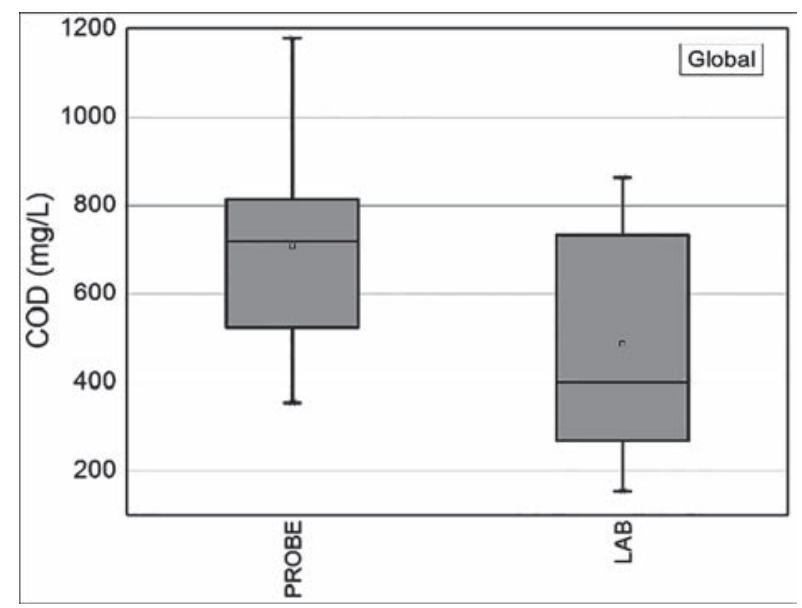

(a)

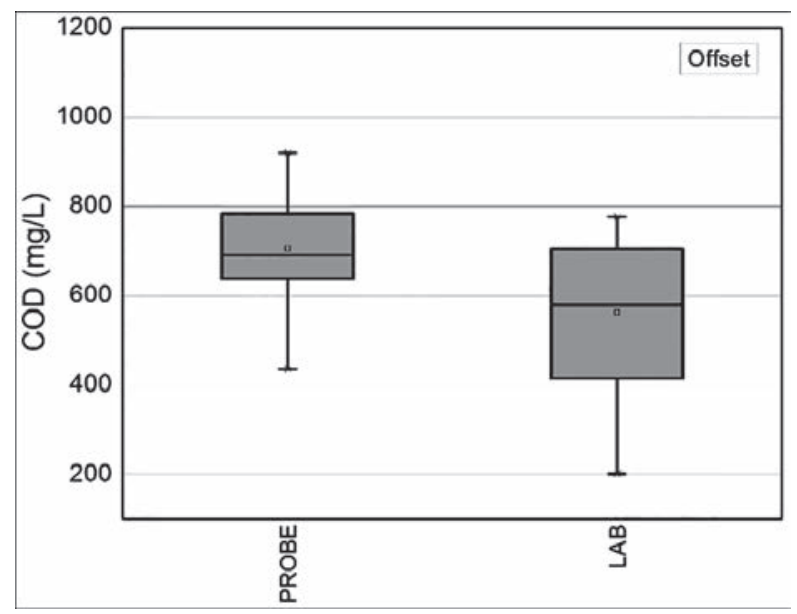

(b)

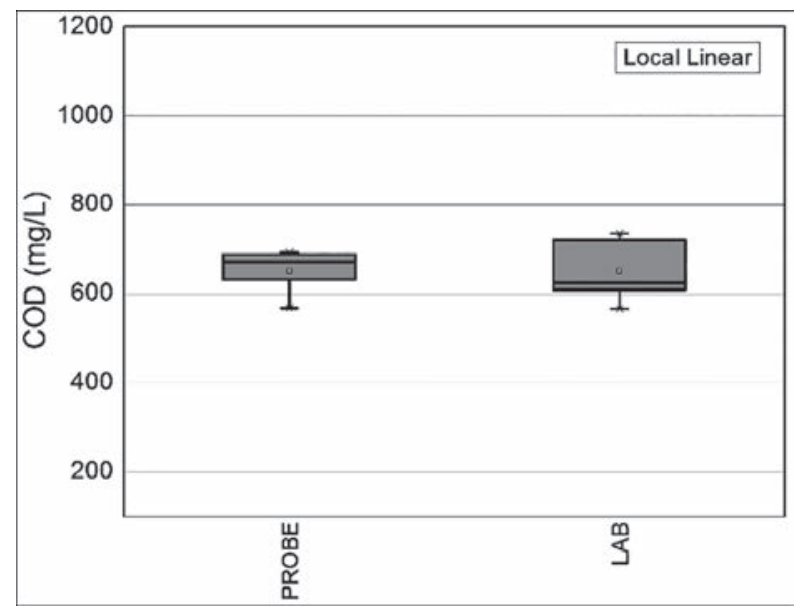

(c)

Figure 3 - Boxplot charts for the affluent: (a) global calibration; (b) local offset calibration; (c) linear local calibration. 


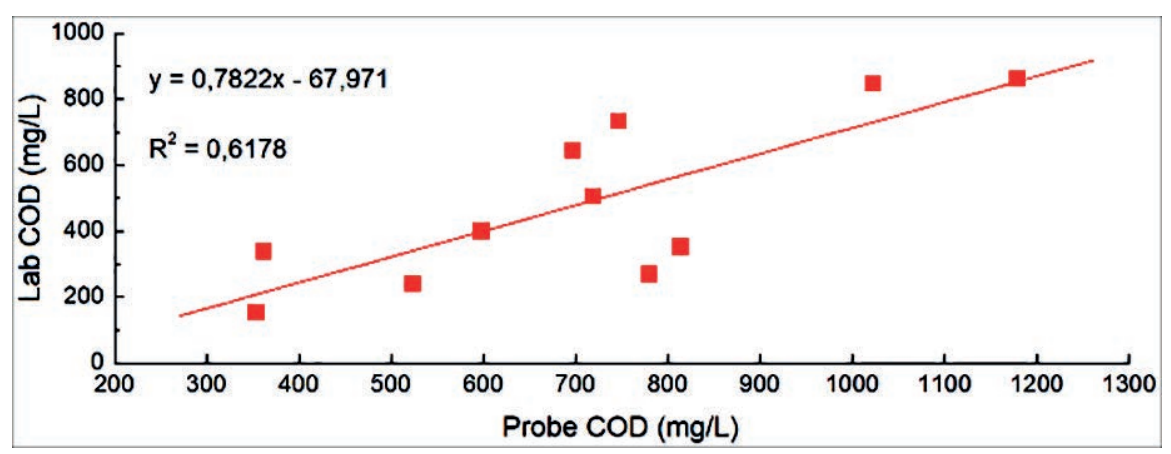

(a)

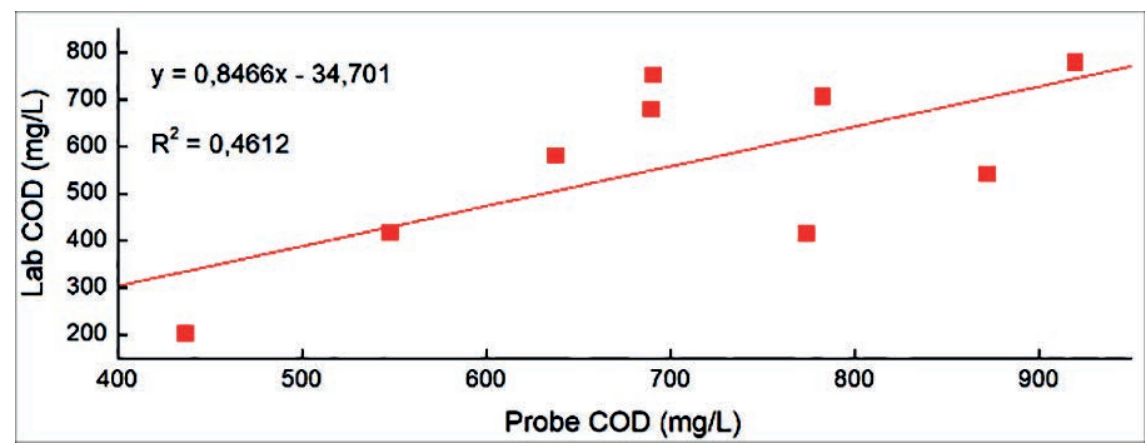

(b)

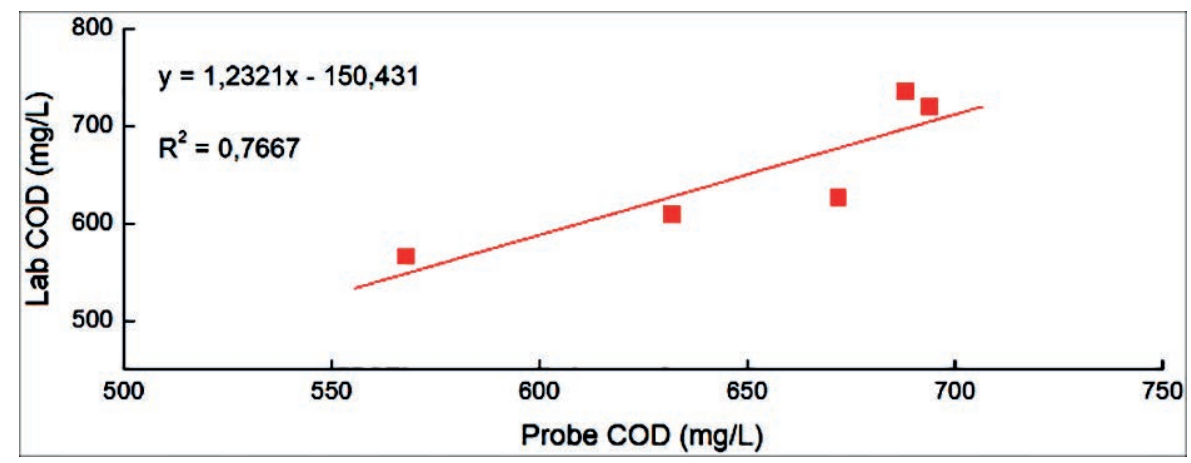

(c)

Figure 4 - Affluent CODlaboratory vs. probe dispersion scatter plots: (a) global calibration; (b) local offset calibration; (c) local linear calibration.

The relative error between the probe and the laboratory values for the effluent are shown in Figure 5.

Between readings \#1 and \#9 (manufacturer global calibration) the observed a verage error is $51.66 \% \pm 35.60$; for the measurement days from \#10 to \#19 (local offset calibration) the found error is $27.53 \pm 24,11 \%$; for the sa mples \#20 to \#24 the recalibrated probe (local linear calibration) has shown a $n$ a verage error of $10.09 \pm 1.95 \%$. 


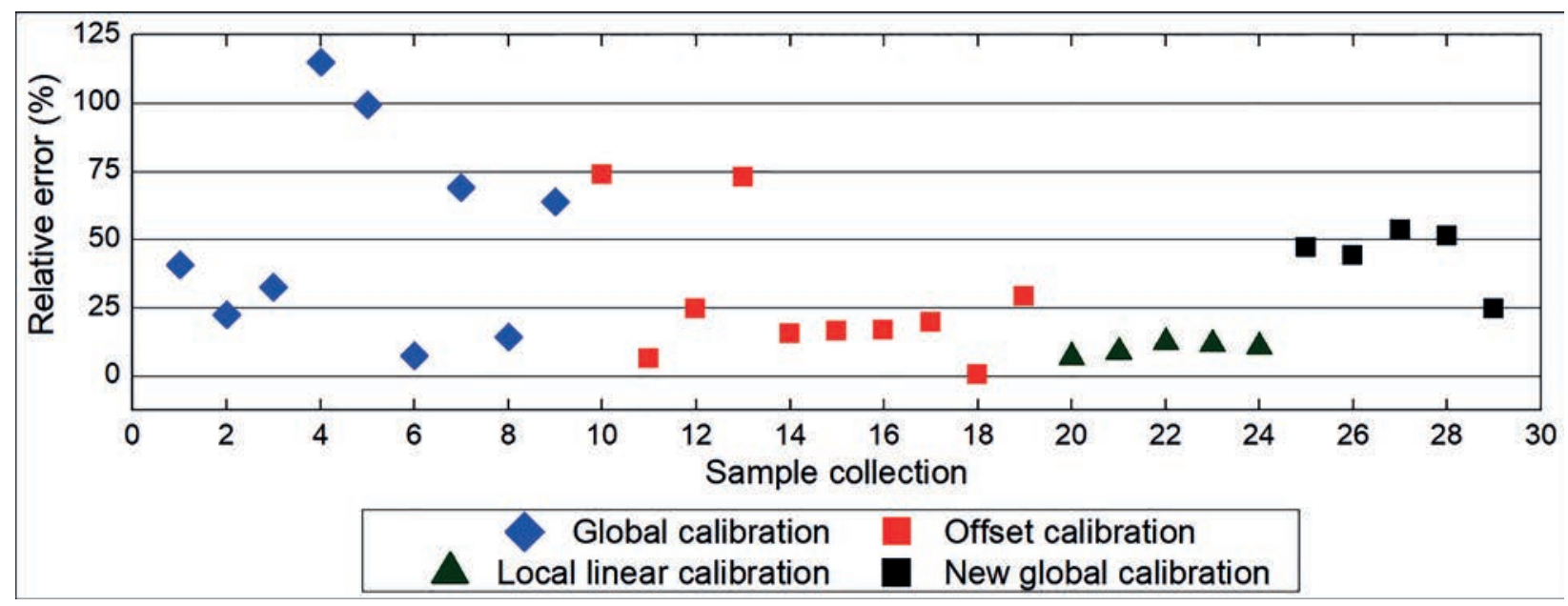

Figure 5 - Effluent COD relative error dispersion scatter plot for: (a) global calibration; (b) local offset calibration; (c) local linear calibration; (d) new global calibration.

As for the affluent samples, the increased cleaning frequency improved the probe performance for effluent samples from collection day \#14. Besides the previous three calibration scenarios, a new global calibration was supplied by the probe manufacturer, with a verage relative error of $44.14 \pm 10.25 \%$. The effluent COD values can be seen in Figure 6 , for the four different calibration conditions.

The probe has not shown the expected adherent behavior for the wastewater effluent. Forglobal calibration (Figure 6a) measurements with the probe showed average COD of $319 \pm 73 \mathrm{mg} / \mathrm{L}$ and laboratory results of $225 \pm 68 \mathrm{mg} / \mathrm{L}$. For local offset calibration (Figure $6 \mathrm{~b}$ ) the results were $277 \pm 60 \mathrm{mg} / \mathrm{L}$ with the probe and $241 \pm 53 \mathrm{mg} /$ Lat the laboratory. Local linearcalibration results (Figure $6 c$ ) were
$242 \pm 4 \mathrm{mg} / \mathrm{L}$ with the probe and $270 \pm 9$ $\mathrm{mg} / \mathrm{L}$ at the la boratory. Finally, a verage COD results were $114 \pm 43 \mathrm{mg} / \mathrm{L}$ with the probe and $204 \pm 74 \mathrm{mg} / \mathrm{L}$ at the laboratory for the new global calibration.

The application of Student's t-test ind ic a ted that only offset calibration has not showed signific ant difference between probe and laboratory mea surements, rejecting the other three conditions.

Figure 7 shows the determination coeffic ient $R^{2}$ for the effluent in the four studied calibration scenarios. The $R^{2}$ equals 0,3845 for global calibration (Figure 7a), 0,1246 for loca I offset c a libration (Figure 7b), 0,5566 for local linear c a libration (Figure 7c) and 0,7927 for the new global calibration (Figure 7d). 


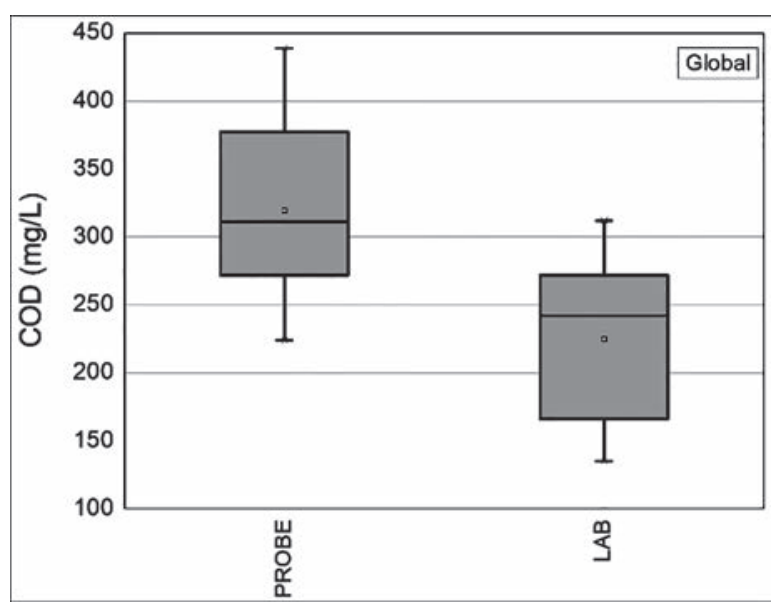

(a)

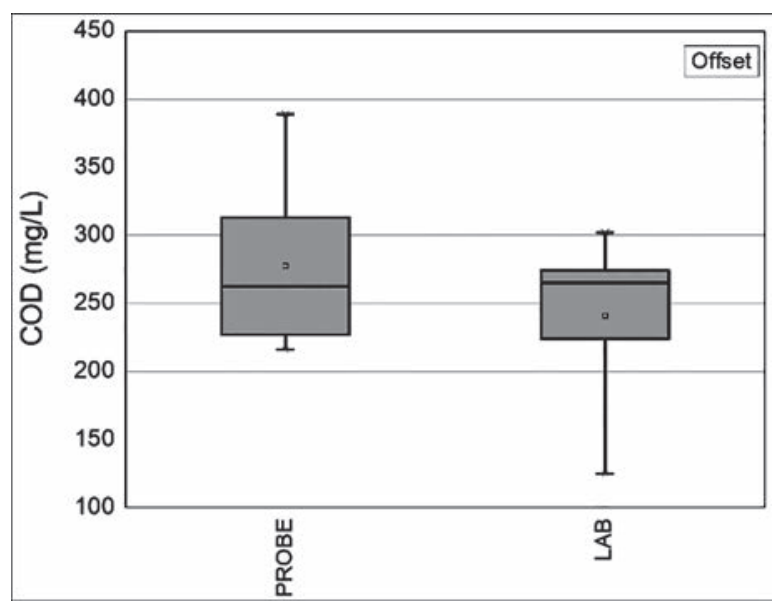

(b)

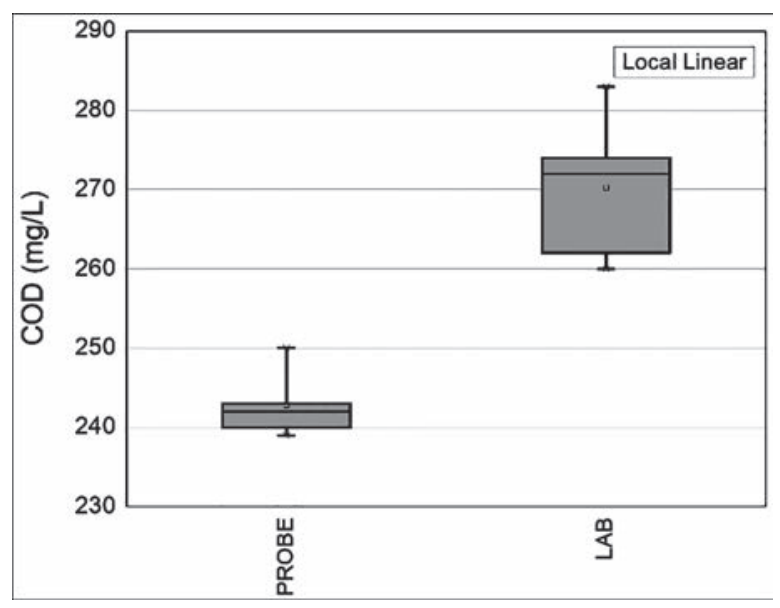

(c)

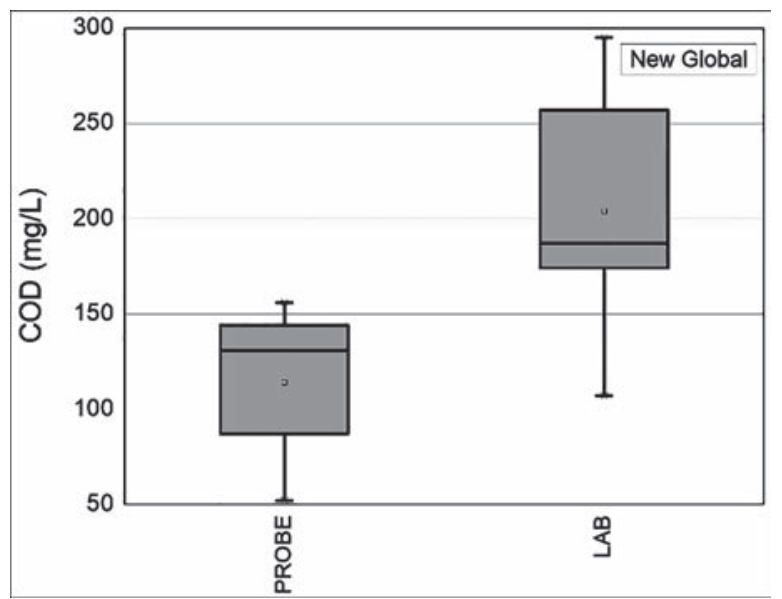

(d)

Figure 6 - Effluent boxplot charts for the different calibration scenarios: (a) global calibration; (b) local offset calibration; (c) local linear calibration; (d) new global calibration.

\section{Other Comments}

One possible explanation for the difference between probe and laboratory mea surements is that the spectrophotometer detec ts only the organic matter fraction absorbing in the UV/VIS range, e.g. organic acids and carbon hydrates. The laboratory analysis detects sulfide, chloride and Fe(II) ions by dichromate oxidation. If the probe spectrophotometer has not the ability to detect ion species, field measurements should give lower COD values. According Figures 4 and 7 , this is the case only for the wastewater effluent and only forlocal linear and new global calibrations.

The probe has the important ability to mea sure, besides COD, total suspended solids. J oint c a libration can allow fitting the parameters of the initia lly built intrinsic software model (Gruber et al., 2006). This can improve the supplier's global calibration, which has not shown reliable values for the effluent. 


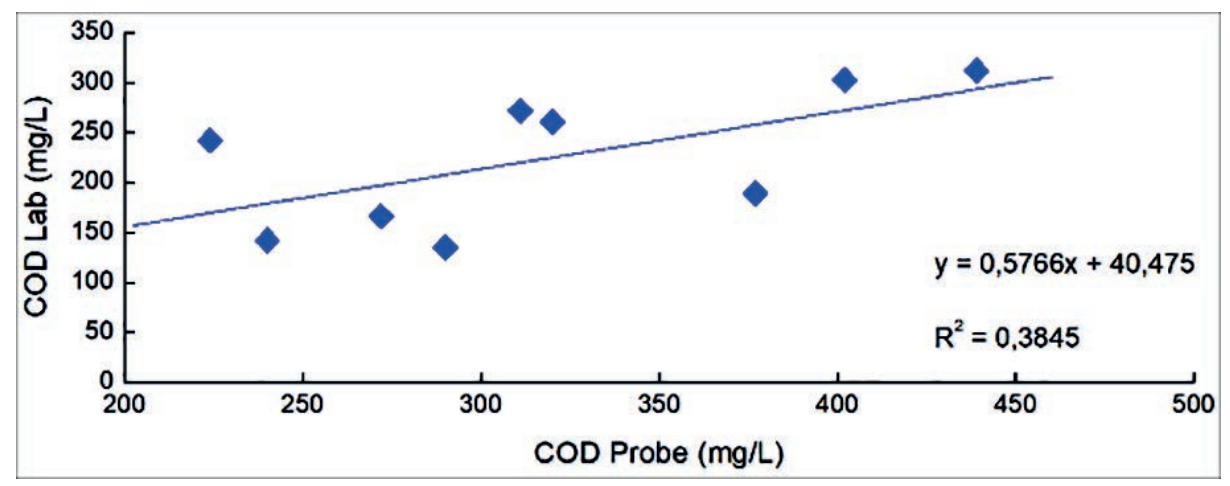

(a)

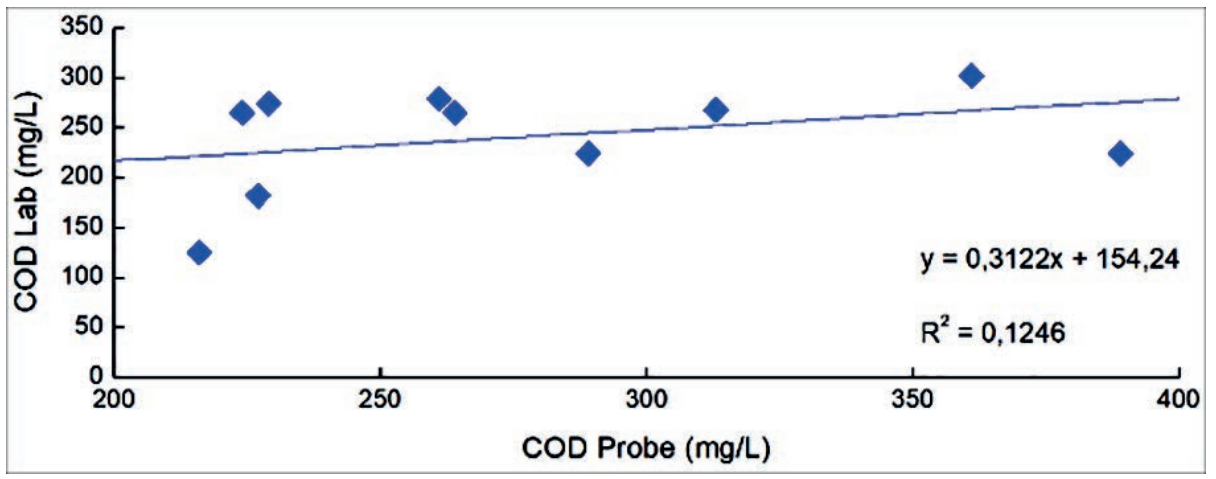

(b)

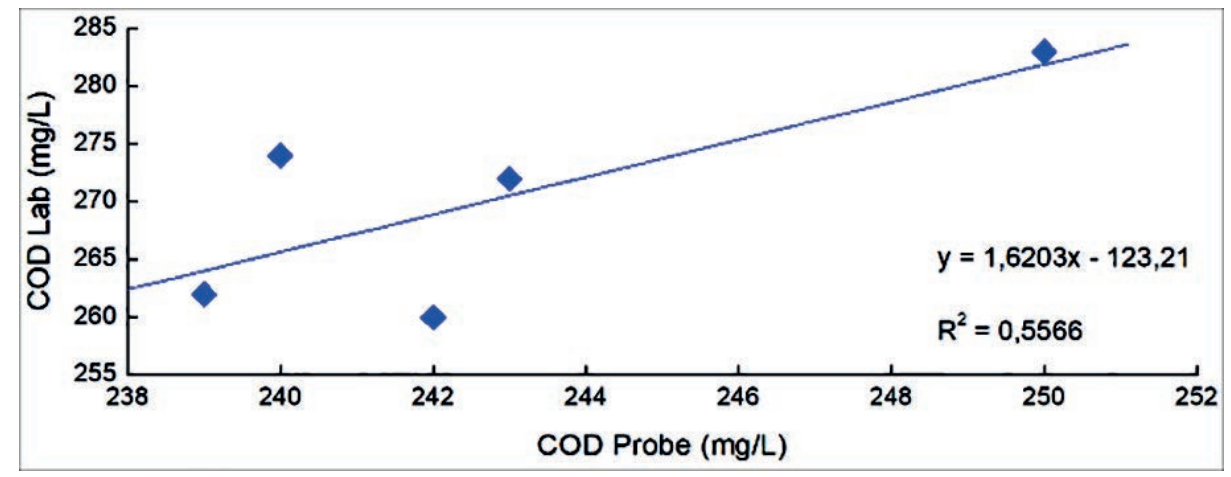

(c)

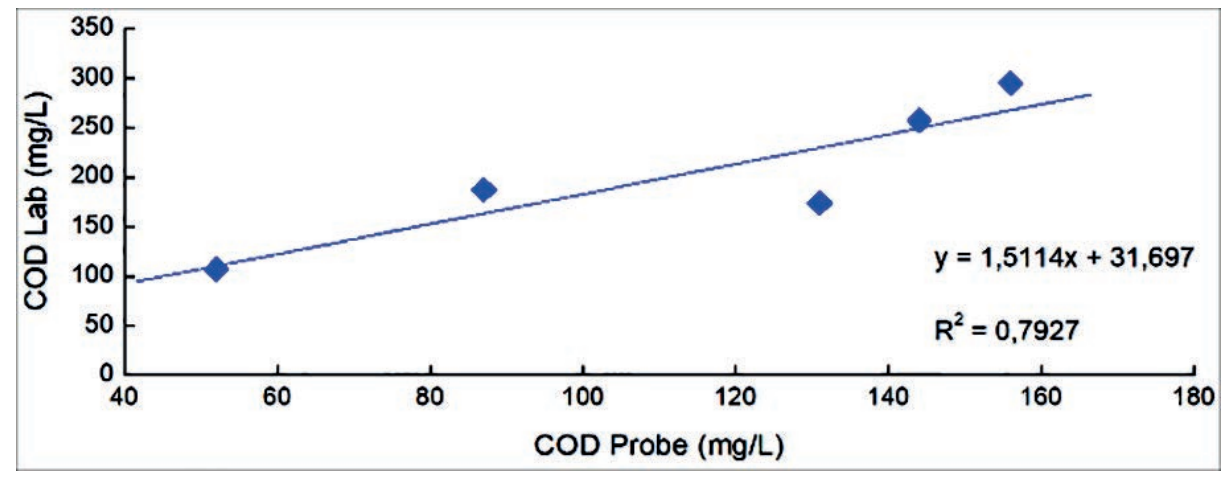

(d)

Figure 7 - Dispersion scatter plots for calibration modes: (a) global calibration, (b) local offset calibration, (c) local linear calibration, (d) new global calibration. 
It is worth mentioning that this study is the first attempt to use spectrophotometry for a ssessment of COD in wastewater trea tment UASB reactors, a successful tec hnology for urban drainage. The local linearcalibration is the best adapted configuration for affluent wastewater monitoring and it also has shown the sma ller rela tive errors for effluent sa mples.

\section{Operationa 1 Aspects}

It is mandatory to avoid a ir bubbles, optic al window hindrance and other measurement interfering phenomena (VANRO LLEG HEM et a I., 2003). The se phenomena were recurrent in this study, including obstruction and clogging of the pipeline connecting the effluent/affluent boxes to the probe site. The frequency of retention valves cleaning and pumps ma intenance was increased to mitigate these problems. Feeding pump flow speeds lowerthan $3 \mathrm{~m} / \mathrm{s}$ ensured the measurement quality. Weekly ma intenance and cleaning of submersible pumps kept the optical window free of impurities, which could encumber the measurement. Additionally, distilled water and detergent together with manual brushing completed the cleaning process.

Air cleaning systems are an important requirement spec trophoto meter relia bility. If cleaning a ir systems a re not able to remove the grime deposited on the measurement window COD values tend to be increased (drift) (GRUBER et al., 2005). According to Langengraber et al. (2004), Gruber et al. (2005). Air clea ning systems should prevent film formation and growth, but in this study case it was not enough to eliminate the film formed at the window, even using the maximum allowed pressure (5 mbar). The UASB wastewater characteristic s could be the reason for this phenomenon, and additional studies are needed.

Cleaning issues were a specific variable in this study and can be related to calibration modes. Manufacturerglobal calibration is based on standard algorithms developed for typic al a pplic a tions, but wastewater quality matrix can vary with location and wastewater origin. Local c a libration can reflect this va ria bility and produce better estimation results (LANGERG RABER et al., 2004; BRITO et al., 2014). The present study ind ic a tes the importance of local calibration adapted to the brazilian wastewater matrix.

\section{Assessment of Removal Efficiency for UASB reactor}

Table 1 summarizes the UASB reactors performance, with lowest relative error being the choice criterion of collection days. For the chosen collection days, the relative error between probe and laboratory measurements were $10 \%$ for the affluent and $13 \%$ for the effluent. 
Table 1 - UASB reactor performance assessment ${ }^{(1)}$.

\begin{tabular}{lccccccc}
\hline Parameter & Unit & $\begin{array}{c}\text { COD } \\
\text { affluent }^{(2)}\end{array}$ & $\begin{array}{c}\text { COD } \\
\text { effluent }^{(3)}\end{array}$ & $\begin{array}{c}\text { TSS } \\
\text { affluent }^{-}\end{array}$ & $\begin{array}{c}\text { TSS } \\
\text { effluent }\end{array}$ & $\begin{array}{c}\text { COD } \\
\text { efficiency }\end{array}$ & $\begin{array}{c}\text { TSS } \\
\text { efficiency }\end{array}$ \\
\hline Probe & $\mathrm{mg} / \mathrm{L}$ & 682 & 271 & - & - & $60 \%$ & - \\
\hline Laboratory & $\mathrm{mg} / \mathrm{L}$ & 613 & 267 & 196 & 82 & $56 \%$ & $58 \%$ \\
\hline
\end{tabular}

Notes: (1) observation period from January to May 2016, collection schedule from 9 to $11 \mathrm{am}$; (2) values for collection day \#16 on; (3) values for collection days \#14 and \#24.

One can notice that both measurement tec hniques provided similar COD removal effic iency values ( $56 \%$ and $60 \%$ ). For the entire assessment period ( $\mathrm{J}$ anuary to May 2016) COD removal measured at the laboratory was $56.76 \%$, with average of $541 \mathrm{mg} / \mathrm{L}$ at reactor entry and 234 at the exit. These effic iency values a re simila $r$ to the lower limit COD reported by Aisse et al. (2002) and Chemicharo et al. (2015), a uthors who compilated the performance of anaerobic treatment plants in large scale, with focus on brazilian plants. The assessed WTP operates with hydraulic retention timesclose by the rated value.

\section{Conclusions}

The scope of this study was to assess the real time in situ utilization of a spectrophotometric measurement system with COD probein UASB reactor entry and exit of a wastewater treatment plant located in the Paraná State.

Results allow to conclude that monitoring can be effective for the UASB affluent. COD values obta ined with spectrophotometric probe and laboratory colorimetric a nalysis have shown no sta tistically significant difference for three different calibration scenarios. Linear local ca libration is the most a dequate to the WTP wastewater conditions, with average relative error equal to $4.32 \%$, standard deviation of $2.76 \%$ and 0.7667 for the determination coeffic ient.

The probe has not shown the expected adherence for the UASB reactor effluent. Global calibration has not shown any reliable value for the effleuent and only the local offset calibration, a mong four calibration scenarios, has shown no significant difference (average relative error of $27.53 \%$, standard deviation of $24.11 \%$ and determination coeffic ient of $0.1246)$. COD removal efficiency values were between $56 \%$ and $60 \%$, close by the lower limit reported in the literature for brazilian wastewa ter trea tment plants.

Therefore, the applic ation of spec trophoto meter tec hniques consists of an advancement to the real time in situ monitoring of brazilian wastewa ter trea tment plants. Even then the spectrophotometric 
probes could not be considered as wa stewa ter quality indic ators, they allow real time monitoring wastewater trea tment plants. However, it is necessary to first define the best practices to obtain more reliable results. The development of cleaning procedures is a n example of a better practice adequate for the UASB reactor WTP.

\section{Recommendations}

The following recommendations will base future works on the use of spectro photometer techniques in wastewater trea tment plants:

- Improvement of the COD measurement for the effluent with probe operation changes, since the results were not conclusive in this case.

\section{REFERENCES}

AISSE, M.M., LOBATO, M.B., JÜRGENSEN, D. and ALÉM SOBRINHO, P., 2002. Tratamento de Efluentes de Reatores Anaeróbios. (Treatment of Anaerobic Effluents with Discharge of Aerobic Sludge to the UASB Reactor). In: VII Taller e Simposio Latino Americano sobre Digestion Anaerobia. Merida, Mexico.

APHA - AWWA - WEF, 2012. Standard Methods for the Examination of Water and Wastewater.

BRITO R.S., PINHEIRO, H., FERREIRA F., MATOS, J.S. and LOURENÇO, N., 2014. In situ UV-Vis spectroscopy to estimate COD and TSS in wastewater drainage systems. Urban Water Journal, vol. 11.

CHERNICHARO, C., VAN HAANDEL A., AISSE, M.M. and CAVALCANTI, P., 1999. Reatores anaeróbios de manta de lodo. In: CAMPOS, J. R. (coord). PROSAB. Rio de Janeiro ABES, p.55-198.

CHERNICHARO, C.A.L., VAN LIER J., NOYOLA, A.R., and BRESSANI T., 2015. Anaerobic sewage treatment: state of the art, constraintsand challenges. Environ Sci Biotechnol, vol. 14, pp. 649-679.
- Building of global calibration curves adequate for the Brazilian wastewater condition, for example, UASB reactors effluent.

- Assessment of behavior and correlations for other variables, also measured with the probe, such as filtered COD and total suspended solids (for UASB affluent and effluent), and the different posttrea tment configurations used for the anaereobic affluent.

\section{Acknowledgements}

The a uthors are grateful to the BrazilGermany Project on Biogas (PROBIOGÁS) for the research funding, and to SANEPAR, UFPR and UFMG for the manifested support. To OEA for the granted studentship during the doctorate course.

GRUBER, G., BERTRAND-KRAJEWSKI, J.L., DE BÉNÉDITTIS, J., HOCHEDLINGER, M. and LETTL, W., 2006. Practical aspects, experiences and strategies by using UV/VIS sensors for long-term sewer monitoring. Water Practice \& Technology, vol. 1.

GRUBER, G., WINKLER, S. and PRESSL, A., 2005. Continuous monitoring in sewer networks- an approach for quantification of pollution loads from CSOs into surface water bodies. Water Science \& Technology. IWA, vol. 52, no. 12, pp. 215-223.

LANGERGRABER, G., WEINGARTENER, A. and FLEISCHMANN, N., 2004. Time- resolved delta spectrometry. A method to define alarm parameters from spectral data. Water Science \& Technology. vol. 50, no. 11, pp. 13-20.

OJEDA, C. B. and SÁNCHEZ, F., 2009. Process analytical chemistry. Applications of ultraviolet/ visible spectrometry in environmental analysis. An overview. Applied Spectroscopy Reviews, vol. 44, pp. 245-265 
RIEGER, L., LANGERGRABER, G. and SIEGRIST, H., 2006. Uncertainties of spectral in situ measurements in wastewater using different calibration approaches. Water Science \& Technology, vol. 53, no. 12, pp. 187-197.

THOMAS, O., BAURÈS, E. and POUET, M., 2005. UV spectrophotometry as a non-parametric measurement of water and wastewater quality variability. Water Quality Research Journal, Canada. vol. 40, no. 1, pp. 51-58.

THOMAS, O., THERAULAZ, F., CERDA, V., CONSTANT, D. and QUEVAUVILLER, P., 1997. Wastewater quality monitoring. Trends in analytical chemistry, vol. 16, pp. 419-424.
VAN DER BROEKE, J., LANGERGRABER, G. and WIENGARTNER, A., 2006. On-line and in-situ UV/VIS spectroscopy for multi-parameter measurements: a brief review. Spectroscopy europe, vol. 18, p. 28.

VANROLLEGHEM, P.A. and LEE, D.S., 2003. On-line monitoring equipment for wastewater treatment processes. state of the art. Water Science \& Technology, vol. 47, pp. 1-34. 